\title{
PENERAPAN ART THERAPY UNTUK MENGURANGI PERILAKU AVOIDANCE DALAM GAD PADA DEWASA AWAL YANG BEKERJA
}

\author{
Helen $^{1}$, Monty P. Satiadarma ${ }^{2}$, dan Rismiyati E. Koesma ${ }^{3}$ \\ ${ }^{1}$ Fakultas Psikologi, Universitas Tarumanagara, Jakarta \\ Email: helen.717171006@stu.untar.ac.id \\ ${ }^{2}$ Fakultas Psikologi, Universitas Tarumanagara, Jakarta \\ Email: montys@fpsi.untar.ac.id \\ ${ }^{3}$ Fakultas Psikologi, Universitas Tarumanagara, Jakarta \\ Email: ristetty@gmail.com
}

\begin{abstract}
ABSTRAK
Generalized Anxiety Disorder (GAD) memiliki perilaku menghindar yang dilakukan secara berulang ketika mengalami kecemasan yang berlebihan. Perilaku menghindar dijadikan sebagai bentuk koping untuk mengurangi perasaan cemas tersebut, sehingga individu menjadi tergantung pada perilaku menghindar dan cenderung akan dilakukan kembali ketika menghadapi kecemasan di lain waktu. Dalam penelitian ini, sebagian besar partisipan dengan usia sekitar 22-28 tahun dengan subyek sebanyak 5 perempuan dan 1 laki-laki melaporkan bahwa kecemasan menyebabkan perubahan dalam pekerjaan dan kegiatan sehari-hari, sehingga terganggunya aktivitas sehari-hari dan pekerjaan menjadi tidak optimal. Perilaku menghindar diukur dengan Multidimensional Experiental Avoidance Questionnaire (MEAQ) dan dan tingkat kecemasan GAD diukur dengan menggunakan skala The GAD7. Penelitian ini menggunakan metode kualitatif untuk menggambarkan perilaku menghindar dan metode kuantitatif untuk melihat efektivitas art therapy dalam mengurangi perilaku menghindar dan menurunkan tingkat kecemasan pada dewasa awal. Teknik pengambilan sampel dengan menggunakan metode snowball sampling. Pemberian art therapy pada masing-masing subyek dilakukan sebanyak tujuh sesi. Dalam penelitian ini, art therapy telah terbukti dapat mengurangi perilaku menghindar dan menurunkan tingkat kecemasan pada dewasa awal yang sedang bekerja dengan menunjukan perubahan perilaku menghindar dan tingkat kecemasan sebelum dan sesudah intervensi. Keberhasilan penelitian art therapy ini juga dipengaruhi oleh adanya kesadaran para partisipan untuk secara konsisten dalam mengikuti sesi terapi.
\end{abstract}

Kata Kunci: generalized anxiety disorder, perilaku menghindar, art therapy, dewasa awal

\begin{abstract}
Generalized Anxiety Disorder (GAD) includes repeating avoidance behavior when experiencing excessive anxiety. Avoidance behavior is a coping mechanism to reduce anxiety, resulting in individuals become dependent on avoidance behavior and tend to repeat it again when facing anxiety in the future. In this study, most participants aged around 22-28 years with as many as 5 women and 1 man reported that anxiety caused changes in work and daily activities, where there is disruption of daily activities and work become less than optimal. Avoidance behavior is measured by Multidimensional Experiental Avoidance Questionnaire (MEAQ) and GAD anxiety levels are measured using The GAD-7 scale. This study uses qualitative methods to describe avoidance behavior and quantitative methods to see the effectiveness of art therapy in reducing avoidance behavior and reducing anxiety levels in young adults. The sampling method used was snowball sampling method. Administration of art therapy in each subject was done in seven sessions. In this study, art therapy is shown to reduce avoidance behavior and reduce anxiety levels in working young adults by the changes in avoidance behavior and anxiety levels after intervention. The success of this art therapy research is also influenced by the consistency of subjects' participation in therapy sessions.
\end{abstract}

Keywords: generalized anxiety disorder, avoidance behavior, art therapy, young adults

\section{PENDAHULUAN \\ Latar belakang}

GAD dikarakteristikan sebagai kecemasan yang berlebihan dan persisten sehingga kekhawatiran yang terjadi tidak dapat dikontrol. Penderita GAD memiliki perasaan cemas yang berlebihan dan persisten tentang kejadian internal dan eksternal dalam kehidupan sehari-hari (Cuijpers, 
Sijbrandij, Koole, Huibers, Berking, \& Andersson, 2014). Begitu pula menurut Klingler (2014) GAD adalah kecemasan umum yang ditandai oleh kecemasan berlebihan dan tidak dapat dikendalikan sehingga menganggu kemampuan penderita untuk berfungsi secara normal. Penderita GAD seringkali mencemaskan ancaman pada masa depan sehingga kekurangan perhatian yang cukup untuk memperhatikan realita pada saat ini.

Berdasarkan data yang didapatkan dari World Health Organization (2017) diperkirakan gangguan kecemasan pada tahun 2015 mencapai 3,6\% di dunia. Dari persentase tersebut dapat diperkirakan terdapat sebanyak 264 juta individu yang mengalami gangguan kecemasan. Di Indonesia, data dari Riset Kesehatan Dasar (2013) melaporkan bahwa terdapat 14 juta penduduk mengalami gangguan mental emosional, termasuk gangguan kecemasan. Populasi individu dewasa di Indonesia mencapai sekitar 150 juta dan sekitar 1.740 .000 atau sebanyak 11,6\% mengalami gangguan kecemasan (Lusia, 2011).

Berdasarkan hasil perhitungan yang dilakukan oleh Agung Frijanto, selaku Ketua Pusat Dokter Spesialis Kedokteran Jiwa menyatakan bahwa terdapat 570 ribu penduduk Jakarta mengalami gangguan kecemasan (Rizal, 2017). Jika dilihat berdasarkan penelitian yang dilakukan oleh Rahayu (2016) ditemukan bahwa gangguan kecemasan yang sering terjadi di masyarakat Jakarta dengan prevelensi cukup tinggi adalah generalized anxiety disorder (GAD).

Ketua Umum Pengurus Pusat Perhimpunan Dokter Spesialis Kedokteran Jiwa Indonesia (PDSKJI) Danardi Sosrosumihardjo mengatakan dalam praktek sehari-hari, gangguan cemas yang sering ditemukan adalah GAD. GAD memiliki presentase sekitar 50\% terjadi pada individu dewasa awal di Jakarta (Tsani, 2015; Rahayu, 2016). Hasil survey yang dilakukan Diferiansyah, Septa, dan Lisiswanti (2016) menunjukkan individu GAD memiliki perilaku avoidance. Perilaku avoidance digunakan sebagai bentuk koping untuk meredamkan perasaan cemas sehingga individu menjadi tergantung pada perilaku avoidance dan cenderung akan dilakukan kembali ketika menghadapi kecemasan di lain waktu. Dengan kata lain, Individu GAD yang memiliki perilaku avoidance yang rendah akan memiliki reaksi untuk mengembangkan koping yang lebih positif, memiliki pengolahan emosi yang baik dan mengembangkan respon melawan dalam menghadapi kecemasan.

Dalam penelitian yang dilakukan oleh Diferiansyah, Septa, dan Lisiswanti (2016) dilaporkan bahwa individu GAD memiliki beberapa gejala seperti merasa cemas, ketegangan motorik, hiperaktivitas, kekhawatiran terhadap sesuatu hal yang tidak pasti, kesulitan berkonsentrasi, gelisah, kesulitan tidur, sering berdebar tanpa sebab yang jelas, dan sakit kepala. Selain itu, juga ditemukan bahwa individu GAD memiliki rasa cemas yang dialami bersifat hilang timbul. Di saat perasaan cemas sedang muncul, dapat menyebabkan individu tidak bisa bekerja secara optimal, cenderung memilih diam di rumah, atau meninggalkan pekerjaan.

GAD memiliki perilaku yang disebut dengan vicious circle behavior. Vicious circle behavior adalah perilaku tertentu yang dilakukan secara berulang ketika individu mengalami kecemasan. Perilaku ini akan muncul apabila individu merasa kesulitan dalam melakukan koping sehingga perasaan cemas dijadikan sebagai bentuk kompensasi atas dirinya yang mengalami kesulitan dalam mencari perasaan aman (Stevens, Jendrusina, Sarapas, dan Behar, 2014). Terdapat dua model respon penghindaran. Model pertama, kekhawatiran dijadikan sebagai upaya kognitif untuk mencegah terjadinya peristiwa negatif dan/atau mempersiapkan diri apabila terjadi peristiwa negatif. Model kedua, saat melakukan respon penghindaran, individu dapat mengurangi rasa ketakutan sesaat terhadap stimulus yang ditakutkan dan mengurangi respon 
somatik. Kedua model respon penghindaran memberikan reinforcement negatif sehingga menghalangi pengolahan emosi yang terkait dengan stimulus rasa takut (Borkovec, 1994; Borkovec, Alcaine, \& Behar, 2004). Dari penjelasan ini diketahui bahwa individu GAD cenderung melakukan respon penghindaran sebagai bentuk koping dalam menghadapi perasaan cemas yang tidak dapat dijelaskan atau berlebihan. Perilaku menghindar cenderung digunakan untuk menghadapi ancaman di masa depan. Perilaku ini merupakan salah satu masalah psikologis yang perlu diatasi dengan pemberian terapi, seperti art therapy.

Art therapy dapat digunakan pada individu untuk memunculkan strategi koping yang positif dalam menangani emosi, faktor lingkungan, situasi, stres dan hubungan secara efektif (Jane, 2018). Art therapy juga bisa dinilai sebagai sebuah aktivitas karya seni yang dapat memenuhi kebutuhan psikologis dan emosional individu. Salah satu aktivitas art therapy adalah mengambar. Chambala menambahkan (2008) art therapy merupakan terapi yang sangat cocok untuk penderita gangguan kecemasan karena art therapy mampu mengekspresikan diri dengan menciptakan bentuk, warna, dan desain seringkali lebih bermanfaat daripada hanya mengandalkan kata-kata untuk ekspresi diri dan komunikasi.

Intervensi art therapy dapat dilakukan di Indonesia karena terdapat penelitian yang dilakukan oleh Joseph, Satiadarma, dan Koesma (2018) menyatakan bahwa art therapy dapat mengurangi kecemasan pada perempuan korban kekerasan dalam rumah tangga di Jakarta. Hasil penelitian ini senada dengan pandangan menurut Rosal (2016) bahwa art therapy dapat menciptakan gambaran dari ketakutan, kecemasan dan solusi yang dibayangkan dalam proses pembuatan karya seni. Solusi yang dibayangkan membantu individu beradaptasi dengan situasi baru dan menyelesaikan masalah, menghilangkan stres dan meningkatkan koping.

Berdasarkan penjabaran penelitian dan fenomena di atas, peneliti merasa pentingnya penanganan terhadap permasalahan psikologis tersebut. Hal ini juga yang membuat peneliti terinspirasi untuk melakukan penelitian pada GAD dengan perilaku avoidance pada dewasa awal yang sedang bekerja. Salah satu alternatif intervensi yang dapat dilakukan yaitu art therapy.

Bentuk kecemasan yang paling umum dialami oleh dewasa awal adalah generalized anxiety disorder (GAD). Gejala GAD dapat terjadi setiap waktu, sehingga akan menganggu kegiatan bekerja pada individu dewasa awal. Gejala GAD yang dimaksud sepertu kesulitan konsentrasi, kesulitan mengontrol kecemasan, mudah Lelah, ketegangan otot, gangguan tidur, mudah marah, dan kegelisahan. Gejala ini harus berlangsung sekurang-kurangnya selama 6 bulan (American Psychiatric Association, 2000).

Penderita GAD memiliki kecenderungan yang berlebihan dalam memperhatikan potensi ancaman, pertentangan, ketakutan, atau kebutuhan yang tidak terpenuhi, sehingga individu merasa tidak dapat mengatasi situasi tersebut dan merasa lebih cemas. Di saat perasaan cemas meningkat, individu mencoba mencegah dan mengurangi kecemasan dengan menunjukkan perilaku avoidance. Perilaku avoidance yang muncul merupakan salah satu bentuk koping dari individu yang mengalami gangguan GAD. Koping yang dirasakan mampu meredam perasaan cemas atau gangguan GAD ini memiliki kecenderungan untuk dilakukan berulang pada situasi yang menstimulus perasaan cemas individu. Oleh karena itu, individu menjadi tergantung pada perilaku avoidance sebagai perilaku untuk mendapatkan safety behavior (Stevens, Jendrusina, Sarapas, dan Behar, 2014). 
Gangguan kecemasan khususnya GAD merupakan suatu gangguan psikologis yang cenderung kompleks secara pemahaman serta penyelesaiannya. Art therapy adalah terapi yang dapat membantu individu dengan gangguan GAD. Art therapy memiliki teknik terapi dengan menggunakan media seni, proses kreatifitas, untuk mengeksplorasikan perasaan, konflik emosi, meningkatkan kedasaran diri, dan mengontrol perilaku. Melalui kreativitas seni, individu penderita GAD dapat melepaskan emosi, menumbuhkan pemikiran positif, mengekspresikan diri dan mengembangkan kemampuan koping terhadap berbagai situasi di lingkungan (Gary, 2015).

Berdasarkan penjabaran di atas, maka peneliti merumuskan permasalahan yang akan dijawab dalam penelitian ini adalah, apakah art therapy dapat menurunkan perilaku avoidance dalam GAD pada dewasa awal yang sedang bekerja?

\section{Landasan teori}

\section{Generalized Anxiety Disorder (GAD)}

Menurut Lader (2015) GAD memiliki karakteristik yang ditandai oleh kekhawatiran yang berlebihan, persisten, dan tidak terbatas dalam keadaan tertentu. Begitu pula dengan pendapat menurut Bandelow dan Michaelis (2015) GAD memiliki kecemasan yang berlebihan dan sulit di kontrol terhadap berbagai kejadian atau aktivitas dalam kehidupan sehari-hari. Individu yang menderita GAD ditandai dengan gelaja fluktuasi dari waktu ke waktu sebagai respons terhadap stressor kehidupan yang akan bertahan selama lebih dari 10 tahun.

\section{Perilaku avoidance}

Penelitian yang dilakukan oleh Rosliani dan Ariati (2016) menyebutkan bahwa gangguan perilaku dapat muncul akibat kecemasan yang tidak teratasi, dapat berupa perilaku avoidance. Perilaku avoidance dapat didefinisikan sebagai ketidakmauan untuk terlibat ke dalam pikiran, perasaan, memori, dan pengalaman pribadi yang bersifat negatif (Gamez, Chmielewski, Kotov, Ruggero, dan Watson, 2011). Perilaku avoidance akan muncul ketika adanya hal tertentu yang dicemaskan. Kecemasan ini ditunjukkan dengan adanya intensi untuk terlepas dari kondisi tersebut sehingga terjadilah respon menghindar (Monarth \& Kase, 2007). Jadi, dari pengertian sebelumnya dapat disimpulkan bahwa perilaku avoidance adalah respon alternative bagi individu untuk menghindari stimulus kecemasan yang tidak dapat teratasi sehingga muncul perilaku avoidance untuk terlepas dari situasi tersebut.

\section{Art therapy}

Morris (2014) mengintegrasikan art therapy ke dalam cognitive behavioral art therapy. Pada penelitian tersebut, Morris menggunakan dua subyek pertisipan yang satunya didiagnosa panic disorder and agoraphobia (PDA) dan yang lainnya didiagnosa GAD. Morris (2014) menemukan bahwa art therapy dapat menurunkan kecemasan secara signifikan pada kedua individu tersebut. Program intervensi ini diakui sebagai komponen penting dari terapi GAD karena art therapy dapat menciptakan gambaran ketakutan dan kecemasan, serta solusi terhadap gambarangambaran tersebut (Rosal, 2016).

\section{Kerangka berpikir dan hipotesis}

Bentuk kecemasan yang paling umum dialami oleh dewasa awal adalah adalah generalized anxety disorder (GAD). Gejala GAD dapat terjadi setiap waktu, sehingga akan menganggu kegiatan bekerja pada individu dewasa awal. Gejala GAD yang dimaksud seperti kesulitan konsentrasi, kesulitan mengontrol kecemasan, mudah lelah, ketegangan otot, gangguan tidur, mudah marah dan kegelisahan. Gejala ini harus berlangsung sekurang-kurangnya selama 6 bulan. 
Penderita GAD memiliki kecenderungan yang berlebihan dalam memperhatikan potensi ancaman, pertentangan, ketakutan, atau kebutuhan yang tidak terpenuhi, sehingga individu merasa tidak dapat mengatasi situasi tersebut dan merasa lebih cemas. Di saat perasaan cemas meningkat, individu mencoba mencegah dan mengurangi kecemasan dengan menunjukkan perilaku avoidance. Perilaku avoidance yang muncul merupakan salah satu bentuk koping dari individu yang mengalami gangguan GAD. Koping yang dirasakan mampu meredam perasaan cemas atau gangguan GAD ini memiliki kecenderungan untuk dilakukan berulang pada situasi yang menstimulus perasaan cemas individu. Oleh karena itu, individu menjadi tergantung pada perilaku avoidance sebagai perilaku untuk mendapatkan safety behavior.

Gangguan kecemasan khususnya GAD merupakan suatu gangguan psikologis yang cenderung kompleks secara pemahaman serta penyelesaiannya. Terdapat salah satu terapi yang dapat membantu individu dengan gangguan GAD, yaitu art therapy. Art therapy adalah sebuah teknik terapi dengan menggunakan media seni, proses kreatifitas, untuk mengeksplorasikan perasaan, konflik emosi, meningkatkan kedasaran diri, dan mengontrol perilaku. Melalui kreativitas seni, individu penderita GAD dapat melepaskan emosi, menumbuhkan pemikiran positif, mengekspresikan diri dan mengembangkan kemampuan koping terhadap berbagai situasi di lingkungan.

Berdasarkan penjabaran diatas, adapun hipotesis yang diambil untuk menjawab permasalahan yang diajukan dalam penelitian ini adalah art therapy dapat menurunkan perilaku avoidance dalam GAD pada dewasa awal yang sedang bekerja.

\section{METODE PENELITIAN}

Masing-masing partisipan memiliki karakteristik yang dibutuhkan dalam penelitian ini, yaitu: (a) individu berjenis kelamin perempuan/laki-laki, (b) sedang berada dalam tahapan dewasa awal 22-28 tahun, (c) partisipan mengalami generalized anxiety disorder yang didapatkan dari hasil tes yang diberikan yaitu $G A D-7$ dan (d) partisipan memiliki kemampuan fisik yang baik untuk dapat berkomunikasi dan menjalani proses intervensi. Penelitian ini tidak dibatasi oleh suku bangsa atau ras, agama, dan status sosial. Selama proses pelaksanaan intervensi art therapy, peneliti tidak melakukan kontrol terhadap warna yang digunakan oleh partisipan. Partisipan dalam penelitian yang didapatkan berjumlah 6 orang, yang terdiri dari lima orang perempuan dan satu orang laki-laki. 5 orang perempuan diantaranya adalah SND (23 tahun), CNT (23 tahun), FN (26 tahun), RC (24 tahun), CF (24 tahun), dan seorang laki-laki dengan inisial PT(27 tahun). Dari hasil screening alat ukur The GAD-7 didapatkan bahwa keenam partisipan memiliki tingkat GAD dalam kategori moderate (rentang skor 10-14).

Teknik pengambilan sampel berupa snowball sampling, adalah suatu metode untuk mengidentifikasi, memilih dan mengambil sampel dalam suatu jaringan atau rantai hubungan yang menerus. Dengan teknik ini, jumlah informan yang akan menjadi subyeknya akan terus bertambah sesuai kebutuhan dan terpenuhinya informasi.

Desain penelitian yang digunakan dalam penelitian ini adalah mixed method dengan menggabungkan metode penelitian secara kuantitatif dan kualitatif dalam satu penelitian. Penelitian ini menggunakan pre-test dan post-test untuk melihat peran terapi seni dalam mengurangi perilaku menghindar.

Proses kuantitatif pada penelitian ini diawali dengan screening melalui sampel dalam suatu jaringan atau rantai hubungan yang menerus dengan menggunakan alat ukur The GAD-7 yang 
sudah diadaptasi ke Bahasa Indonesia untuk melihat apakah partisipan memiliki kencenderungan mengalami gangguan kecemasan, khususnya GAD. Setelah itu, peneliti akan memberikan alat ukur The Multidimensional Experiental Avoidance Questionnaire (MEAQ) yang sudah diadaptasi ke dalam Bahasa Indonesia untuk melihat apakah partisipan melakukan perilaku menghindar terhadap kecemasannya. Apabila partisipan memenuhi kriteria penelitian ini, barulah peneliti melakukan proses wawancara. Setelah sesuai dengan kriteria penelitian, partisipan akan diikutsertakan pada proses intervensi art therapy. Ketika memasuki tahap terminasi partisipan diminta untuk mengisi kembali kuesioner MEAQ untuk melihat efektivitas intervensi art therapy.

Beberapa contoh pertanyaan dalam panduan wawancara, yaitu : (a) Apakah Anda melakukan perilaku menghindar ketika merasa cemas?; (b) Apakah kecemasan yang Anda hadapi menghambat Anda dalam melakukan kegiatan/pekerjaan sehari-hari?; (c) Dampak apa yang Anda rasakan dari adanya kecemasan ini?; (d) Upaya apa yang Anda lakukan untuk mengatasi kecemasan yang muncul pada saat bekerja?

Dalam penelitian ini, peneliti menggunakan intervensi dari Morris yang terdiri dari 7 tahapan. Tahap pertama, disebut dengan my anxiety circle, tujuan dari terapi ini untuk memperoleh informasi yang abstrak tentang kecemasan. Tahap kedua, disebut dengan my support system, bertujuan untuk mengembangkan strategi koping. Tahap ketiga, dikenal dengan depict unlikely cognition dan depict likely cognition. Depict unlikely cognition untuk mengenali perilaku avoidance selama mengalami kecemasan sedangkan depict likely cognition, menumbuhkan koping positif dan mengurangi perilaku avoidance. Tahap keempat merupakan tahapan relaksasi untuk melepaskan ketegangan otot ketika terdeteksi isyarat kecemasan. Tahapan ini disebut dengan water color breathing technique. Tahap kelima dikenal dengan fear hierarchy, berfungsi untuk conceptualize situation (mengartikan situasi). Tahap keenam adalah least feared situation pieces dengan tujuan meningkatkan kemampuan koping. Tahap terakhir, disebut bridge drawing berfungsi untuk melihat perkembangan partisipan selama menjalani intervensi.

Dalam setiap sesi, peneliti akan memberikan diary anxiety kepada setiap partisipan penelitian. Diary anxiety sebagai media untuk mengenali tingkat kecemasan partisipan sehari-hari dengak skala 1 ("teramat sangat tidak cemas") sampai 10 ("teramat sangat cemas). Pemberian diary anxiety ini bertujuan untuk melihat efektivitas dari program intervensi art therapy yang diterapkan. Diary anxiety yang diisi oleh partisipan merupakan sebuah peringkat skala untuk menilai level kecemasan umum karena adanya penghindaran.

Tabel 1. Gambaran prosedur pelaksanaan program intervensi.

\begin{tabular}{|c|c|c|c|c|}
\hline Sesi & Art therapy & Tugas Rumah & Peralatan & Waktu \\
\hline 1 & "My Anxiety Cycle" & Diary anxiety & $\begin{array}{l}\text { Acrylic, Kuas, Kertas gambar A3, } \\
\text { majalah }\end{array}$ & 90 menit \\
\hline 2 & “My Support System” & Diary anxiety; & Acrylic, Kuas, kertas gambar A3 & 90 menit \\
\hline 3 & $\begin{array}{l}\text { Depict Unlikely cognition } \\
\text { dan Depict likely cognition } \\
\text { version }\end{array}$ & Diary anxiety; & Acrylic, Kuas, kertas gambar A3 & 90 menit \\
\hline 4 & $\begin{array}{l}\text { Watercolor } \quad \text { breathing } \\
\text { technique }\end{array}$ & Diary anxiety; & Watercolor, Kuas, kertas gambar A3 & 90 menit \\
\hline 5 & Fear hierarchy & Diary anxiety & Acrylic, Kuas, kertas gambar A3 & 90 menit \\
\hline 6 & Least-feared situation pieces & Diary anxiety & Acrylic, Kuas, kertas gambar A3 & 90 menit \\
\hline 7 & Bridge Drawing & N/A & Acrylic, Kuas, kertas gambar A3 & 90 menit \\
\hline
\end{tabular}


Format quasi experimental desain ini menggunakan format A-B withdrawal yang melibatkan fase baseline (A) dan fase perlakuan (B). Rancangan intervensi fase baseline (A), partisipan diberikan post-test terlebih dahulu untuk mengetahui tingkat kecemasan dan perilaku menghindar sebelum dilakukan intervensi. Setelah itu, peneliti memberikan diary anxiety kepada partisipan untuk diisi selama dua minggu. Fase perlakuan (B) akan di adakan selama empat minggu. Sesi intervensi art therapy dilakukan sebanyak 7 sesi dalam empat minggu. Selama proses intervensi peneliti juga mewawancarai partisipan setiap sesinya untuk mengetahui perasaan-perasaan partisipan setelah menyelesaikan masing-masing sesi tersebut. Selama fase perlakuan, partisipan tetap melanjutkan diary anxiety sampai berakhirnya fase perlakuan. Kemudian akhir dari penelitian dilanjutkan dengan post-test mengisi Multidimensional Experiental Avoidance Questionnaire (MEAQ). Hal tersebut dilakukan untuk melihat apakah para partisipan sudah berhasil menurunkan perilaku menghindar setelah menjalani proses intervensi art therapy.

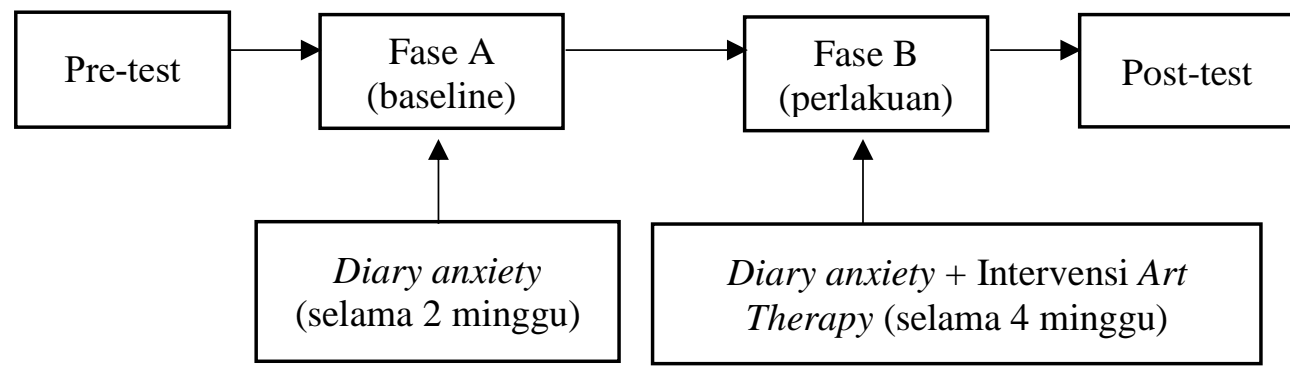

Gambar 1. Visualisasi Desain Penelitian

\section{HASIL DAN PEMBAHASAN}

Berdasarkan alat ukur Multidimensional Experiental Avoidance Questionnaire (MEAQ) diketahui bahwa adanya penurunan kecemasan pada masing-masing partisipan. Gambaran penurunan perilaku menghindar dapat dilihat pada table 2 berikut.

Tabel 2. Tabel perbandingan pre-test \& post-test MEAQ antar partisipan

\begin{tabular}{llcc}
\hline \multirow{2}{*}{ No. } & \multirow{2}{*}{ Inisial Partisipan } & \multicolumn{2}{c}{ Skor Total } \\
\cline { 3 - 4 } & & Pre-Test MEAQ & Post-Test MEAQ \\
\hline 1 & SND & 210 & 183 \\
\hline 2 & CNT & 205 & 184 \\
\hline 3 & FN & 206 & 183 \\
\hline 4 & CF & 202 & 177 \\
\hline 5 & RC & 200 & 177 \\
\hline 6 & PT & 212 & 185 \\
\hline
\end{tabular}

Dari hasil tabel 2 diatas, dapat dilihat bahwa keenam partisipan mengalami penurunan skor total pada alat ukur Multidimensional Experiental Avoidance Questionnaire setelah menjalani tuju sesi intervensi art therapy dalam bentuk menggambar. Hal ini menunjukkan bahwa keenam partisipan telah berhasil menurunkan perilaku menghindar dan meningkatnya koping positif. Akan tetapi terdapat perbedaan penurunan skor dari keenam partisipan. Partisipan RC mengalami penurunan skor yang paling besar, yaitu sebanyak 14 poin. Partisipan CNT mengalami penurunan skor sebanyak 12 poin. Partisipan SND mengalami penurunan skor sebanyak 11 poin. Partisipan PT mengalami penurunan skor sebanyak 10 poin. Partisipan FN mengalami penurunan skor sebanyak 9 poin. Sedangkan partisipan $\mathrm{CF}$ hanya mengalami penurunan skor sebanyak 5 poin. 


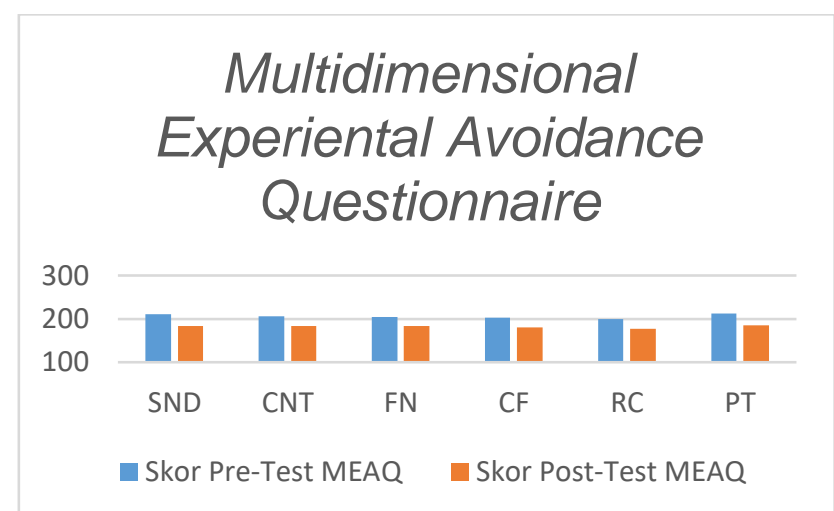

Grafik 1. Perbandingan hasil skor MEAQ per-partisipan

Terdapat penurunan rata-rata skor total Multidimensional Experiental Avoidance Questionnaire pada pre-test dan post-test (Grafik 1). Rata-rata skor total keenam partisipan pada pre-test alat ukur Multidimensional Experiental Avoidance Questionnaire sebesar 205,8 sedangkan post-test sebesar 182. Selisih rata-rata skor total kelima partisipan pada pre-test dan post-test alat ukur Multidimensional Experiental Avoidance Questionnaire sebesar 23.8 poin (Grafik 2). Hal ini menunjukkan bahwa art therapy dalam bentuk menggambar dapat menjadi media untuk menurunkan perilaku menghindar dan meningkatkan strategi koping positif yang dilakukan oleh keenam partisipan. Berdasarkan data hasil uji statistik non-parametrik the Wilcoxon Ranked test menunjukkan bahwa art therapy dalam bentuk menggambar dapat secara signifikan menurunkan angka perilaku menghindar dari keenam dewasa awal yang terlibat dalam penelitian ini $(\mathrm{Z}=$ $2.214, \mathrm{p}=.027)$.

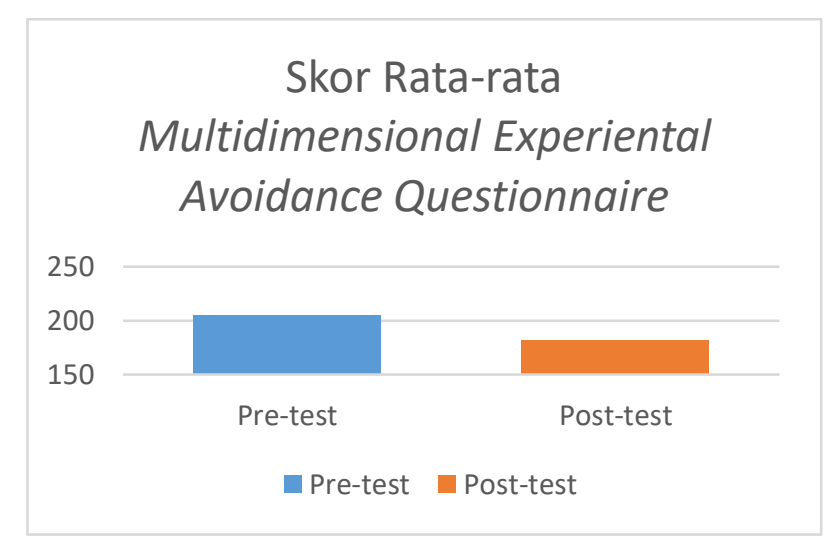

Grafik 2. Perbandingan skor rata-rata MEAQ

Tabel 2. Perbandingan baseline \& intervensi skor rata-rata tingkat kecemasan antar partisipan

\begin{tabular}{llcc}
\hline \multirow{2}{*}{ No. } & Inisial Partisipan & \multicolumn{2}{c}{ Skor Rata-Rata Tingkat Kecemasan } \\
\cline { 3 - 4 } & & Baseline & Intervensi \\
\hline 1 & SND & 7 & 5.5 \\
\hline 2 & CNT & 7.1 & 6 \\
\hline 3 & FN & 6.1 & 5 \\
\hline 4 & CF & 6.1 & 5.1 \\
\hline 5 & RC & 6.5 & 5.8 \\
\hline 6 & PT & 6 & 5.3 \\
\hline
\end{tabular}

Terdapat penurunan rata-rata skor total tingkat kecemasan pada fase baseline dan intervensi (Tabel 2). Pada keenam partisipan setelah menjalani tujuh sesi intervensi art therapy dalam 
bentuk menggambar. Hal ini menunjukkan bahwa keenam partisipan telah berhasil menurunkan tingkat kecemasan. Akan tetapi terdapat perbedaan penurunan skor rata-rata dari keenam partisipan. Partisipan SND mengalami penurunan skor yang paling besar, yaitu sebanyak 14 poin. Partisipan CNT mengalami penurunan skor sebanyak 1.50 poin. Partisipan CNT, FN, dan CF mengalami penurunan skor sebanyak 1.10 poin. Partisipan PT dan RC mengalami penurunan skor sebanyak .70 poin (Grafik 3).

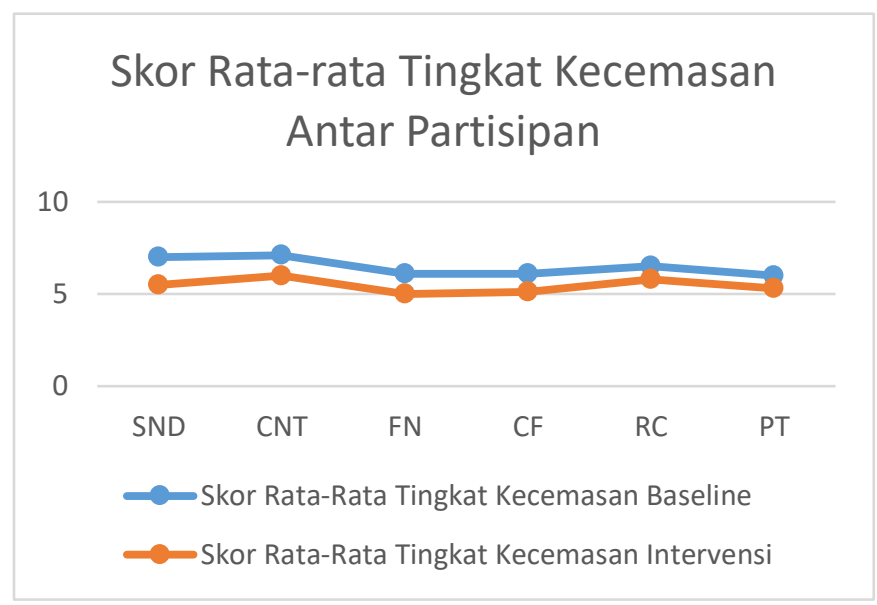

Grafik 3. Perbandingan skor rata-rata tingkat kecemasan

Berdasarkan data hasil uji statistik non-parametrik the Wilcoxon Ranked test menunjukkan bahwa art therapy dalam bentuk menggambar dapat secara signifikan menurunkan tingkat kecemasan dari keenam dewasa awal yang terlibat dalam penelitian ini $(Z=-2.214, p=.027)$.

Art therapy merupakan terapi yang sangat cocok untuk penderita gangguan kecemasan karena art therapy mampu mengekspresikan diri dengan menciptakan bentuk, warna, dan desain seringkali lebih bermanfaat daripada hanya mengandalkan kata-kata untuk ekspresi diri dan komunikasi (Chambala, 2008). Dalam hal ini art therapy dijadikan sebagai media untuk mengungkapkan perasaan-perasaan yang sulit untuk diungkapkan secara verbal. Melalui art therapy seseorang dapat melepaskan ketidaksadarannya seperti ketakutan, tekanan, hal-hal yang tidak dapat diterima secara sadar baik bagi diri orang tersebut. Ketidaksadaran dilepaskan melalui ekspresi seni, sehingga partisipan dapat melakukan asosiasi bebas dan menjadi media untuk sublimasi, salah satu bentuk defence mechanism (Edwards, 2004). Dengan terungkapnya perasaan-perasaan yang terpendam dalam diri partisipan melalui proses pembuatan karya seni, maka tekanan-tekanan dalam diri mereka yang sebelumnya tidak dapat diungkapkan dapat dikeluarkan.

Keenam partisipan berhasil mengembangkan koping positif pada sesi keenam yaitu pada tahap least feared situation pieces. Setelah menggambar situasi yang lebih positif, para partisipan merasa lega, senang, semangat, dan lebih percaya diri. Menurut Malchiodi (2012) seni dapat membuat partisipan membentuk kembali bagaimana perasaan partisipan dalam menanggapi peristiwa atau pengalaman yang dicemaskan. Serta bekerja pada perubahan emosional dan perilaku. Art therapy memungkinkan partisipan untuk secara aktif mencoba bereksperimen atau melatih perubahan yang diinginkan melalui gambar, lukisan, atau kolase. Setelah mereka melatih untuk menghadapi perubahan positif maka munculkan perasaan lega, senang, semangat, dan muncul dorongan dalam diri untuk menjadi pribadi yang lebih optimis. 
Ide positif seperti harapan dan optimis juga muncul dalam proses art therapy pada seluruh partisipan di sesi ketujuh. Pada sesi ini, seluruh partisipan diminta untuk menggambar jembatan yang mengisahkan kehidupan mereka. Gambar jembatan yang dihasilkan oleh seluruh partisipan rata-rata memiliki keyakinan dan pemikiran positif untuk meningkatkan kualitas kehidupan di masa sekarang dan masa depan. Hal ini dikarenakan melalui media gambar, partisipan akan memahami persepsi dan perasaan yang terjadi pada diri mereka, sehingga persepsi dan perasaan ini akan membantu partisipan untuk menemukan cara dalam memecahkan masalah dan menemukan harapan (Gary, 2015).

Salah satu hal yang mendukung keberhasilan dari intervensi ini adalah setiap partisipan menikmati mengerjakan setiap aktivitas seni mereka, mereka melakukannya dengan tekun dan semangat. Para partisipan mengerjakan gambar tanpa terganggu dengan suasana lingkungan sekitarnya dan tampak puas ketika telah menyelesaikan gambarnya. Dalam aktivitas ini para partisipan memegang kontrol sepenuhnya dengan apa yang ingin mereka lakukan tanpa intervensi dari manapun, sesuatu yang jarang mereka dapatkan ditengah lingkungan kerja yang stres. Dari pembuatan gambar visual, partisipan dapat mensublimasi perasaan ke dalam gambar atau melalui komunikasi dengan terapis dari objek yang digambar, sehingga setelah pembuatan karya seni para partisipan merasa puas karena telah mengungkapkan perasaan yang terpendam (Waller, 2006).

Hal lain yang mendukung berhasilnya intervensi ini adalah adanya keterlibatan partisipan untuk terlibat dalam menggerjakan suatu tugas serta keberanian partisipan untuk menyampaikan informasi kepada peneliti (Mukhlis, 2011). Instruksi yang diberikan oleh peneliti selalu diikuti oleh para partisipan. Pada awal sesi hingga akhir sesi, seluruh partisipan memiliki sikap yang sangat koperatif untuk mengikuti sesi intervensi dan terlihat sungguh-sungguh dalam pembuatan seni.

\section{KESIMPULAN DAN SARAN}

\section{Kesimpulan}

Target dari penelitian ini adalah ingin mengurangi perilaku menghindar dengan menggunakan penerapan art therapy pada dewasa awal yang memiliki gangguan GAD. Dari keenam partisipan menunjukkan adanya penurunan kecemasan secara signifikan dari perubahan skor total MEAQ dan skor rata-rata tingkat kecemasan.

\section{Saran}

Saran yang dapat diberikan untuk dewasa awal yang memiliki perilaku menghindar, termasuk partisipan penelitian ini adalah sebaiknya para dewasa awal memiliki koping yang positif terhadap kecemasan yang dialami, seperti menuangkan perasaan yang terpendam melalui media gambar bukan melakukan perilaku menghindar terhadap hal tertentu yang dicemaskan untuk mendapatkan kegelaan sesaat.

Selanjutnya, bagi para partisipan disarankan untuk melakukan pengulangan aktivitas intervensi dengan menggunakan media gambar kembali, terutama seperti yang dilakukan pada sesi ke enam dari program intervensi ini, yaitu dengan menggambar situasi positif yang diimajinasikan. Tujuan dari sesi ini agar para partisipan dapat mengembangkan koping positif terhadap hal tertentu yang dihindari. Pengulangan aktivitas ini dapat dilakukan secara mandiri, mengingat media yang dibutuhkan untuk program intervensi ini tidak sulit untuk didapatkan. 
Therapist disarankan untuk memanfaatkan intervensi art therapy, khususnya dalam kegiatan menggambar perlu diingat sensitivitas seni dan skill therapist dalam bidang art amat dibutuhkan.

Peneliti juga menyarankan pada peneliti selanjutnya agar melakukan penelitian dengan sampel yang lebih banyak dan metode Randomized controlled trial (RCT).

\section{Ucapan Terima Kasih (Acknowledgement)}

Penelitian ini dilakukan dengan bantuan, dukungan dan masukan dari dari berbagai pihak. Oleh karena itu, peneliti mengucapkan terima kasih dengan tulus kepada semua pihak yang memberikan kontribusinya dalam penelitian ini, antara lain: 1) Bapak Lim Kun Lai dan Ibu Tianni selaku orang tua yang tiada hentinya memberikan dukungan materi dan doa; 2) Responden penelitian, subyek CNT, SND, CF, FN, RC, dan PT atas kesediaannya untuk berpartisipasi dalam penelitian ini.

\section{REFERENSI}

Bandelow, B. \& Michaelis, S. (2015). Epidemiology of anxiety disorder in the 21 st century. Dialogues in clinical neuroscience, 17(3), 1027-1035.

Borkovec, T. D. (1994). The nature, functions, and origins of worry. In G. C. L. Davey \& F. Tallis (Eds.), Wiley series in clinical psychology. Worrying: Perspectives on theory, assessment and treatment. Oxford, England: John Wiley \& Sons.

Borkovec, T. D., Alcaine, O., \& Behar, E. S. (2004). Avoidance theory of worry and generalized anxiety disorder. In R. Heimberg, D. Mennin, \& C. Turk (Eds.), Generalized anxiety disorder: Advances in research and practice. NY, New York: Guilford.

Chambala, A. (2008). Anxiety and art therapy: treatment in the public eye. Journal of Art Therapy Assocation vol, 25(4), 187-189.

Cuijpers, P., Sijbrandij, M., Koole, S., Huibers, M., Berking, M., \& Andersson, G. (2014). Psychological treatment of generalized anxiety disorder: A meta-analysis. Clinical psychology review. https://doi.org/10.1016/j.cpr.2014.01.002.

Diferiansyah, O., Septa, T., Lisiswanti, R. (2016). Gangguan cemas menyeluruh. J medula Unila, 5(2), 63-67. file:///Users/helen/Desktop/1510-2222-1-PB.pdf.

Edwards, R. (2004). Art therapy. London : SAGE Publications, Ltd.

Gámez, W., Chmielewski, M., Kotov, R., Ruggero, C., and Watson, D. (2011). Development of a measure of experiential avoidance: the multidimensional experiential avoidance questionnaire. Psychol. Assess, 23, 692-713. doi: 10.1037/a0023242

Gary, R. (2015). The art of healing and healing in art therapy. InPsych, 37 (3). https://www.psychology.org.au/inpsych/2015/june/gray

Jane, K. J. (2018). Building koping skills, emotional regulation, and insight in preadolescent girls: an expressive art therapy program developmental model. Proquest Disertation. https://search.proquest.com/openview/e9e8e37027950f52fef2b1dcb6c0f75b/1?pqorigsite $=$ gscholar $\&$ cbl $=18750 \&$ diss $=\mathrm{y}$

Joseph, M. C., Satiadarma, M. P., \& Koesma, R. E. (2018). Penerapan terapi seni dalam mengurangi kecemasan pada perempuan korban kekerasan dalam rumah tangga di Jakarta. Jurnal Muara Ilmu Sosial, 2 (1), 77-87. https://journal.untar.ac.id/index.php/jmishumsen/article/viewFile/1620/1156

Klingler, A. M. (2014). Generalized anxiety disorder. Journal of the American Academy of Physician Assistants, 27(8), 42-43. doi:10.1097/01.jaa.0000451864.10330.b4

Lader, M. (2015). Generalized anxiety disorder. Encyclopedia of Psychopharmacology. Berlin: Springer-Verlag Berlin Heidelberg 
Lusia, K. A. (2011, September 29). Kecemasan dan depresi mencapai 11,6\%. Kompas. https://lifestyle.kompas.com

Malchiodi, C. A. (2012). Handbook of art therapy. (2 $2^{\text {nd }}$ ed.,). NY, New York: The Guilford Press.

Morris, F. J. (2014). Should art be integrated into cognitive behavioral therapy for anxiety disorders?. The Arts in Psychotherapy, 41, 343-352.

Monarth, H., \& Kase, L. (2007). The confident speaker: Beat your nerves and communicate at your best in any situation. New York, NY: McGraw-Hill.

Mukhlis, A. (2011) Pengaruh terapi membatik terhadap depresi pada narapidana. Jurnal Psikologi Islam, 8(1), 100-115.

Rahayu, S. (2016). Pencegahan gangguan kecemasan dengan intervensi berbasis web. Jurnal Ilmiah Widya, 3(3), 1-5. https://e-journal.jurwidyakop3.com/index.php/jurnalilmiah/article/view/288/293.

Riset Kesehatan Dasar. (2013). Badan Penelitian dan Pengembangan Kesehatan Kementerian RI tahun 2013. Diakses: 19 May 2018, dari http://www.depkes.go.id

Rizal, B. (2017, September 19). 570 Ribu penduduk Jakarta mengalami gangguan mental emosional. Tribunnews. http://www.tribunnews.com/nasional/2017/09/19/570-ribupenduduk-jakarta-mengalami-gangguan-mental-emosional.

Rosal, M. L. (2016). Cognitive-behavioral Art Therapy Revisited. The Wiley Handbook of Art Therapy. ( $1^{\text {st }}$ ed.,). NY, New York: John Wiley \& Sons, Inc.

Rosliani, N., \& Ariati, J. (2016). Hubungan antara regulasi diri dengan kecemasan menghadapi dunia kerja pada pengurus ikatan lembaga mahasiswa psikologi indonesia (ILMPI). Jurnal Empati, 5(4), 744-749.

Stevens, E. S., Jendrusina, A. A., Sarapas, C., \& Behar, C. (2014). Generalized Anxiety Disorder. The wiley handbook of anxiety disorder. (1 $1^{\text {st }}$ ed.,). NY, New York: John Wiley $\&$ Sons, Inc.

Tsani, T. N. (2015, 14 November). Gangguan kecemasan: Kenali gejala fisiknya. Bisnis.com. http://lifestyle.bisnis.com/read/20151114/220/492096/gangguan-kecemasan-kenaligejala-fisiknya

Waller, D. (2015). Group interactive art therapy: its use in training and treatment. ( $\left.2^{\text {nd }} \mathrm{ed}\right) . \mathrm{NY}$, New York. Routledge.

World Health Organization. (2017). Depression and other common mental disorder: Global health estimate. http://apps.who.int 